\title{
Lesser Kestrel Foraging Habitats in Special Protection
}

\section{Areas in Agro-ecosystems}

\author{
Antonia Galanaki ${ }^{1,2}$, Theodoros Kominos ${ }^{2,3}$ and Martin John Jones ${ }^{1}$ \\ 1. Division of Biology and Conservation Ecology, School of Science and the Environment, Manchester Metropolitan University, \\ Chester Street, Manchester, M1 5GD, UK \\ 2. Raptor Study Group of Greece, Eressou 35, Athens, GR-10681, Greece \\ 3. Department of Zoology, School of Biology, Aristotle University of Thessaloniki, GR-54124 Thessaloniki, Greece
}

\begin{abstract}
The European Union (EU) Wild Birds Directive recognises that the most serious threats to wild birds' conservation in Europe are habitat loss and degradation, and hence, habitats of threatened and migratory species must be protected with the establishment of the network of the special protection areas (SPAs) for migratory and endangered bird species in the EU member states. The major European population of the lesser kestrel Falco naumanni, a migratory falcon listed in Annex I of the Birds Directive, occurs in low-input farming systems in the Mediterranean basin, including Greece. The aim of this study was to identify foraging habitats of lesser kestrels and relate them to the delimited SPAs in the agro-ecosystems of Greece, where the stronghold of the species population for Greece occurs. Foraging habitat preferences were assessed using Poisson regression models (PRMs). SPAs were examined on whether they can effectively protect foraging habitats for breeding lesser kestrels in the study area. Foraging lesser kestrel abundance was positively associated with grasslands and non-irrigated land (dry cereals), and negatively associated with irrigated land (wet cotton), scrubland and woodland. Electricity facilities were used as foraging perches by lesser kestrels. The current SPAs cover a small percentage of the species' foraging sites and cannot be considered coherent enough to support and protect the foraging habitats of lesser kestrels and other priority species in the agro-ecosystems of the study area. Proposals for effective conservation of low-input farming systems, supporting priority species, are also presented.
\end{abstract}

Key words: Falco naumanni, special protection areas (SPAs), Poisson regression models (PRMs), foraging habitats, species conservation, agro-ecosystems, Greece.

\section{Introduction}

The European Union (EU) Wild Birds Directive (Council Directive 2009/147/EEC) recognises that the most serious threats to the conservation of wild birds in Europe are habitat loss and degradation, focusing on the protection of the habitats of endangered and migratory species [1]. Maintenance of the ecological quality of the habitats of priority species, listed in Annex I of the Birds Directive, is a key conservation issue for the preservation of bird diversity in the EU. A network of special protection areas (SPAs) for priority species has been identified and delimited in most EU member states, comprising of wild birds'

Corresponding author: Antonia Galanaki, Ph.D., research field: conservation biology. most suitable breeding and foraging sites, aiming at improving species conservation status at European level [1,2].

The major European population of a protected migratory bird species of lowland Europe, the lesser kestrel Falco naumanni, occurs in low-input farming systems in the Mediterranean basin [3, 4]. Although the lesser kestrel has been down-listed from "vulnerable" to "least concern" in the IUCN Red List of Threatened Species since 2011 [5], it is still an Annex I species of the EU Birds Directive due to its dramatic decline in recent years [1]. Many important lesser kestrel habitats have been designated as SPAs of the Natura 2000 network in EU member states where it breeds $[4,6]$. Based on BirdLife International classification list on species of European conservation 
concern (SPEC), the lesser kestrel is a "SPEC 1" species [7] with $25 \%-49 \%$ of its world population breeding in Europe [8]. At European level, it is a priority species in steppic habitats (i.e., primary steppe, secondary steppe and pseudo-steppe of extensively farmed, mixed rotational systems of grassland, cereal, fodder crops and grazed fallow land) and in arable land and pastures (i.e., land regularly ploughed and/or cultivated for feed and non-feed crops); and its survival is linked with management practices in agro-ecosystems [9]. In the Mediterranean region, the species population had undergone a sharp decline, but it has now recovered in some countries, such as Portugal [4]. In Greece, the species was common in the 1960s, but it also suffered a dramatic decline and its distribution shrunk; it is legally protected and listed as "vulnerable" in the Red Data Book of Threatened Animals of Greece [10]. Nowadays, its population has recovered in mainland Greece and is estimated at 5,400-7,100 breeding pairs [11].

Lesser kestrel habitat selection studies reveal that its populations decline results from changes in agricultural practice and loss or deterioration of its foraging habitats on its breeding grounds [12-21]. However, the criteria for delimiting SPA boundaries for protected birds are not always appropriate, as they are often based solely on nesting distribution [22]. Conservation actions for priority birds should take into account both nesting and foraging requirements and only recently studies have focused on the effectiveness of SPAs for EU priority species [22-29]. Currently, the lesser kestrel is a priory species in 25 designated SPAs within the protected areas of the network of Natura 2000 sites of Greece, with more than $90 \%$ of its population occurring in the agro-ecosystems of central Greece [30, 31].

The aim of this study was to identify important foraging habitats of breeding lesser kestrels and relate those to delimited SPAs in the agro-ecosystems of central Greece, where the stronghold of its breeding population for Greece occurs. Questions on: (1) the lesser kestrel foraging habitat preferences, (2) the information obtained on environmental variables at different spatial extents and incorporated in foraging habitat analysis for conservation purposes and (3) the coherence of SPAs on whether they can effectively protect foraging habitats along with nesting sites for breeders in the study area are assessed and proposals for effective management are presented.

\section{Materials and Methods}

\subsection{Study Area}

The study area is located in the largest agricultural plain of the country, covering approximately 4,000 $\mathrm{km}^{2}$, in the region of Thessaly, central Greece (Fig. 1). Nearly half of the plain is dominated by cultivations of intensive irrigated cotton and non-intensive dry cereal, while pastures are on hilly slopes close to urban areas [32]. The climate is typical continental Mediterranean, characterised by wet, cold winters and dry, hot summers [33]. The elevation in the study area ranges in 0-2,005 $\mathrm{m}$. Five SPAs established in the region of Thessaly include the lesser kestrel as a priority species [31, 32]. Three SPAs "Periochi Thessalikou Kampou" (GR1420011), "Periochi Farsalon" (GR1420012) and "Oros Ossa" (GR1420007) are in the study area (Fig. 1). Two SPAs "Oros Mavrovouni" (GR1420006) and "Periochi Tyrnavou" (GR1420013) are not included in study area, located at its periphery (Fig. 1). The SPAs include urban areas (towns and villages) with lesser kestrel colonies, the presence of which in the study area was mapped in the years 2006 and 2007 [34] (Fig. 1). Other priority species in the SPAs of the study area include the short-toed eagle Circaetus gallicus, the long-legged buzzard Buteo rufinus, the lanner falcon Falco biarmicus, the calandra lark Melanocorypha calandra and the stone curlew Birhunus oedicnemus. 


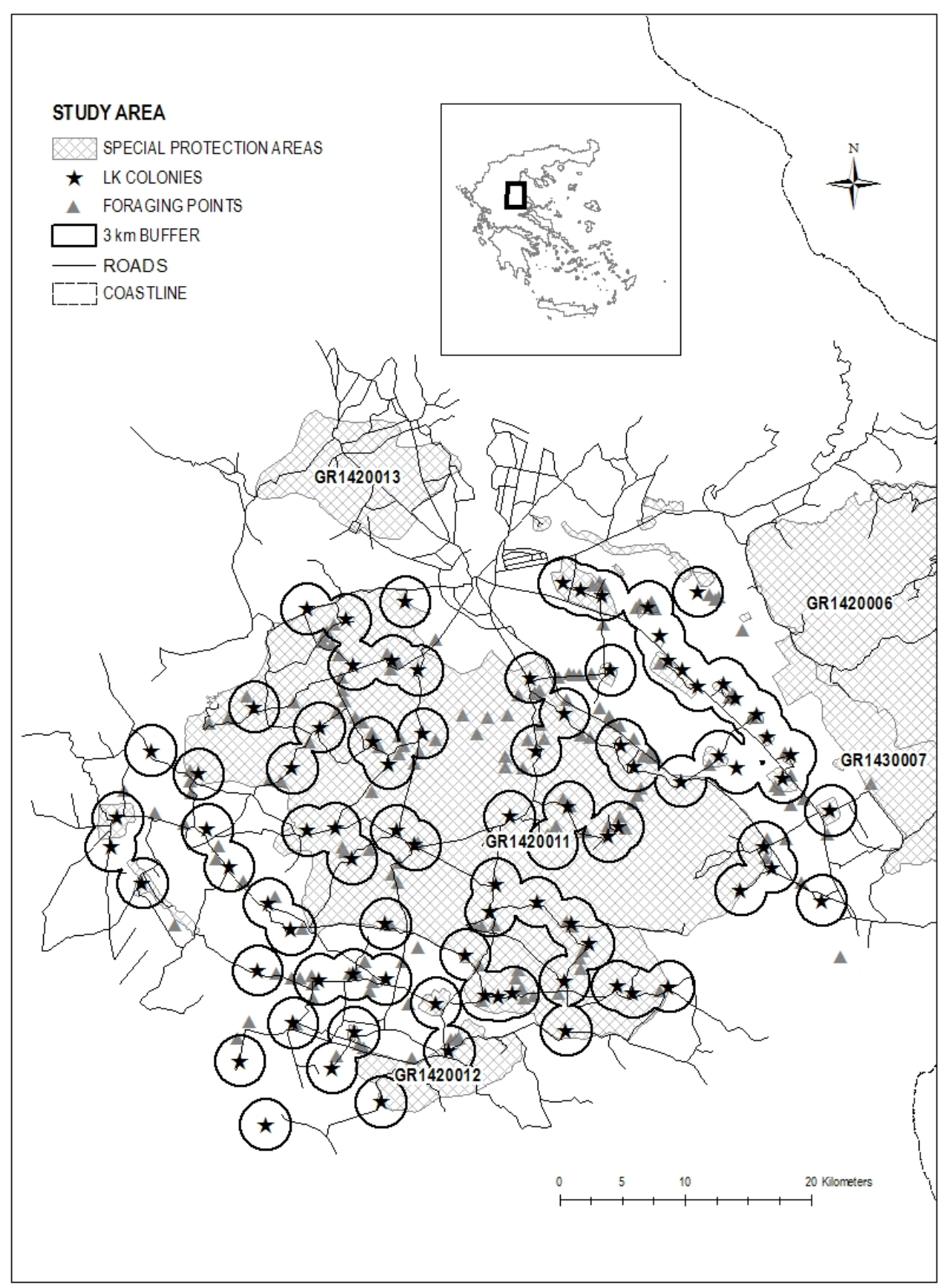

Fig. 1 Map of the study area and the SPAs (cross-hatched areas).

The SPAs GR1420011 (comprised of a larger and many smaller areas), GR1420012 and GR1420007 lie within the study area, while the SPAs GR1420006 and GR1420013 are located at its periphery.

Black stars: the lesser kestrel colonies in the study area; grey triangles: the foraging observation points.

Thick black lines: buffer zones of $3 \mathrm{~km}$ radius around each colony (dissolved between them for overlapping colonies); thin black lines: the network of main roads.

\subsection{Bird Data}

Data on foraging birds were collected along road transects during June and July of 2007. Road counts can be used for large and obvious species, such as raptors, particularly those that hover when searching for food in open habitats $[35,36]$. Road transects can be limited by road availability [37], but the study area 
is open and has a smooth terrain with less tall vegetation, allowing visibility at long distances; counts were made on both sides of the road. Highways were avoided due to speed limitations. Transects involved slowly driving of approximately $30 \mathrm{~km} / \mathrm{h}$ in days of good weather conditions for the detection of birds and frequent stops both when birds were seen but also to search for birds from vantage points [14]. Twenty road transects, on accessible routes of the main and the secondary roads and of the farm tracks in the study area, were randomly selected, covering a length of approximately $2,000 \mathrm{~km}$, and were driven once. The network of main roads in the study area is presented in Fig. 1. Surveys were conducted from sunrise until sunset, considering the fact that lesser kestrels can be active throughout the day [12, 38]. Only those birds considered as "foraging individuals" i.e., hovering over a habitat or landing to catch a prey from the ground or hunting from a perch were recorded as a "foraging observation point" and the position was marked with a global positioning system (GPS) receiver, from the position of the researcher, as close as possible to bird location. The habitat type was identified in the field and each foraging bird was attributed to the habitat type where it was first observed [39].

\subsection{Environmental Data}

To obtain information for lesser kestrel foraging habitat analysis at different scales, sampling plots at two spatial extents around each "foraging observation point" were selected for data retrieval: (1) at a circular buffer of $100 \mathrm{~m}$ radius and (2) at a circular buffer of $500 \mathrm{~m}$ radius. The selection of the extents was based on the determination of the main components of spatial scale which are the "grain size" and "extent size"; according to Legendre, P. and Legendre, L. [40], the former is "the size of the elementary sampling unit" and the latter is the overall area from where observations are made, i.e., extent size is the whole study area [41]. In this study, the grain size was selected at two extents, the sampling plots of $100 \mathrm{~m}$ and $500 \mathrm{~m}$ plots. This information could be used for conservation purposes, for example, for the establishment of effective agri-environmental measures (AEM) [42] and the determination of ecological focus areas (EFA) that should be identified and maintained in large size arable cultivations under the greening of the current EU Common Agricultural Policy (CAP) [43].

Habitat data - used as explanatory variables in the model development - were extracted from a thematic map, produced by a supervised image classification analysis of a Landsat satellite image of $30 \mathrm{~m}$ pixel size resolution [34], obtained from the U.S. Geological Survey for the year 2006 [44]. Seven land cover types (non-irrigated farmland, irrigated farmland, grassland, urban, woodland, scrubland and water) were determined, based on the land cover classes of the EU Programme Corine 2000 [45]. Elevation variables (min, max, mean and standard deviation describing topographic complexity) were derived from a digital elevation model (DEM) of $90 \mathrm{~m}$ pixel size resolution [46] and analyses were performed in ArcGIS [47]. Other researchers have also included elevation variables in lesser kestrel foraging habitat analyses [15].

Other information recorded at foraging observation points includes presence of electricity facilities and field margins when used by birds and were incorporated in the models as categorical explanatory variables. These attributes have been identified as important elements in the vicinity of nesting colonies in the European Species Action Plan [4]. A variable on the "nearest distance-to-colony" (from each foraging observation point) was also calculated using Hawth's tool (v. 3×) [48]. In total, 13 explanatory variables were used for model development (Table 1).

\subsection{GIS-Based Analysis}

GIS-based analysis was used to: (1) examine overlapping of the SPAs with the breeding colonies and 
Table 1 Explanatory variables used for the development of foraging habitat models.

\begin{tabular}{|c|c|}
\hline Variable & Description and units \\
\hline Urban & Urban and other built-up areas and artificial surfaces, such as roads, airports, etc. (\%) ${ }^{*}$ \\
\hline Irrigated & Irrigated agricultural land, dominated by cotton fields and other industrial plants (maize, tobacco) $(\%)^{*}$ \\
\hline Non-irrigated & Non-irrigated agricultural land, dominated by dry cereals (mainly wheat) $(\%)^{*}$ \\
\hline Grassland & Grasslands, pastures and fallow land $(\%)^{*}$ \\
\hline Scrubland & Sclerophyllus vegetation (garrigue and short maquis) $(\%)^{*}$ \\
\hline Woodland & Forest, tall maquis and areas of woody crop plantations and tree groves $(\%)^{*}$ \\
\hline Elevation min & Minimum value of elevation within each polygon $(\mathrm{m})^{*}$ \\
\hline Elevation max & Maximum value of elevation within each polygon $(\mathrm{m})^{*}$ \\
\hline Elevation mean & Mean value of elevation within each polygon $(\mathrm{m})^{*}$ \\
\hline Elevation SD & $\begin{array}{l}\text { Standard deviation of elevation; } \\
\text { a measure of topographic complexity }(\mathrm{m})^{*}\end{array}$ \\
\hline Distance_colony & Distance of each foraging point to the nearest colony $(\mathrm{m})$ \\
\hline Dummy_fmargins & $\begin{array}{l}\text { Dummy of field margins; } \\
\text { Coded as } 1 / 0 ; 1 \text { corresponds to field margins as foraging habitat and } 0 \text { to other foraging habitats } \\
\text { Dummy of electricity facilities, such as wires and poles; }\end{array}$ \\
\hline Dummy_elecwires & $\begin{array}{l}\text { Coded as } 1 / 0 ; 1 \text { corresponds to "presence" and } 0 \text { to "absence" of electricity wires and poles that birds use as } \\
\text { foraging perches }\end{array}$ \\
\hline
\end{tabular}

${ }^{*}$ Measured at two different spatial extents within each sampling plot.

the lesser kestrel foraging sites and (2) obtain information on the habitat types in the SPAs. Spatial data extraction: (1) the extent of the current SPAs and (2) buffer zones of $3 \mathrm{~km}$ radius around each breeding colony (buffers dissolved for overlapping colonies) were respectively overlaid with: (1) the lesser kestrel foraging observation points, (2) the species breeding colonies and (3) the habitat thematic map. The $3 \mathrm{~km}$ radius was selected based on suggestion of the European Species Action Plan, according to that "all nesting locations must provide access (within range 1-3 km) to open areas for hunting, usually in steppe-like habitats, natural or managed grasslands and non-intensively cultivated land" [4]. In this study, the maximum distance of $3 \mathrm{~km}$ radius was selected.

\subsection{Statistical Analysis}

Descriptive statistics were calculated for all explanatory variables in the sampling plots at both spatial extents $(100 \mathrm{~m}$ and $500 \mathrm{~m})$. Dummy variables were used to express the categorical variables for the presence of electricity facilities and field margins (Table 1); for explanatory variables with $c$ categories, $c$-1 dummy variables are needed and a reference category is set in which all dummy variables equal zero [49]. The dummy on electricity facilities was coded as " 1 " for birds using them as foraging perches and as " 0 " if not used. The dummy on field margins was coded as " 1 " when birds were recorded to forage there and " 0 " when birds foraged elsewhere. A principal components analysis (PCA) was applied to remove problems from correlated variables [50]. The principal components $\left(\mathrm{PC}_{\mathrm{S}}\right)$ were used as explanatory variables in the model building. Components were obtained with the varimax rotation [50] and only factors with eigenvalues greater than one were included in the analysis.

For the assessment of lesser kestrel foraging habitat selection, Poisson regression models (PRMs), i.e., generalized linear models for count data [51] were developed with bird count data from the foraging observation points as the response variable and a set of explanatory variables. Residual deviance was first checked for overdispersion [52]. Because overdispersion was detected, Quasi-Poisson models (QPMs) were employed, where the variance was given as function of the mean using a dispersion parameter $\rho$ (i.e., variance $=\rho \times \mu$ ) [53]. All analyses were performed using $R$ (v.2.8.1) [54]. 


\section{Results}

\subsection{Bird Data-Univariate Analysis}

In total, 760 lesser kestrels were recorded along the road transects, at 166 foraging observation points (Fig. 1). Higher aggregations of foraging birds were observed in cereal fields accounting for $77.7 \%$ of all individuals (Table 2). About $15 \%$ of birds were recorded to feed in fallow land and grassland and only a few in cotton fields $(3.2 \%)$ and in field margins $(2.9 \%)$ (Table 2$)$. Mean coverage of irrigated land was $20.4 \%$ at the $100 \mathrm{~m}$ and $32.8 \%$ at the $500 \mathrm{~m}$ extent plots, respectively, while non-irrigated land occupied $37.7 \%$ of the area at the $100 \mathrm{~m}$ and $29.0 \%$ of the area at the $500 \mathrm{~m}$ plots, respectively (Table 3 ). Urban areas covered large parts of plots at both extents (Table 3 ). Both irrigated land and woodland occupied larger areas at the $500 \mathrm{~m}$ compared to the $100 \mathrm{~m}$ plots and topographic complexity (standard deviation of elevation) was also higher in the $500 \mathrm{~m}$ plots than the $100 \mathrm{~m}$ plots (Table 3 ). The mean distance of foraging observation points to the colonies was approximately $1,645 \mathrm{~m}$ (Table 3 ).

\subsection{Principal Components Analysis}

At the $100 \mathrm{~m}$ extent analysis, four principal components (PC1a-PC4a) were extracted accounting for $75.5 \%$ of the total explained variance within the original variables. PC1a was an "elevation" component (Table 4). PC2a was a "habitat and distance" component, referring to scrubland and non-irrigated land; the latter located away from colonies (Table 4). PC3a was a "habitat" component (grasslands located away from irrigated land and woodland), while PC4a was an "urban and habitat" component with urban areas located away from grasslands (Table 4). At the $500 \mathrm{~m}$ extent analysis, four components (PC1b-PC4b) were also extracted accounting for $80.7 \%$ of the original variance. PC1b (Table 5) was an "elevation and habitat" component, including elevation and non-irrigated and irrigated farmland, hilly areas covered with cereals, away from cotton fields. PC2b was also a "habitat" component, describing areas of woodland and irrigated land, away from urban sites (Table 5). PC3b was a mixed "habitat and distance" component, referring to areas covered with scrubland situated away from colonies (Table 5), while PC4b was a "habitat" component, positively related to grasslands (Table 5).

\subsection{Quasi-Poisson Models}

The present study aimed at obtaining information from two different scales on the environmental variables; no comparison of the models performance was conducted. At the $100 \mathrm{~m}$ extent analysis, in QPM1, significant variables were those components related with agricultural and natural habitats and the nearest distance to the colonies; the PC2a was positively and the PC3a was negatively associated with lesser kestrel abundance (Table 6). Also, at the $100 \mathrm{~m}$ extent, the elevation component (PC1a) was significant. At the $500 \mathrm{~m}$ extent analysis, in QPM2, significant components were the elevation and

Table 2 Number of foraging observation points (FOP) recorded at the habitat types as identified in the field and number of birds $(\%)$ recorded at these points.

\begin{tabular}{llll}
\hline $\begin{array}{l}\text { Habitat type (identified in the } \\
\text { field) of FOP }\end{array}$ & Number of FOP & $\begin{array}{l}\text { Number of birds } \\
\text { recorded at FOP }\end{array}$ & $\begin{array}{l}\text { Percentage of birds at each } \\
\text { habitat type (\%) }\end{array}$ \\
\hline Alfalfa field & 3 & 7 & 0.9 \\
Cereal field & 105 & 591 & 77.7 \\
Cotton field & 19 & 24 & 3.2 \\
Fallow land & 26 & 83 & 10.9 \\
Field margin & 8 & 22 & 2.9 \\
Grassland & 4 & 31 & 4.1 \\
Tomato field & 1 & 2 & 0.3 \\
All & 166 & 760 & 100.0 \\
\hline
\end{tabular}


Table 3 Descriptive statistics with mean values and standard deviations (SD) at the $100 \mathrm{~m}$ and $500 \mathrm{~m}$ extents for the explanatory variables used in the models.

\begin{tabular}{|c|c|c|c|c|}
\hline \multirow{2}{*}{ Predictor (units) } & \multicolumn{2}{|c|}{$100 \mathrm{~m}$ extent } & \multicolumn{2}{|c|}{$500 \mathrm{~m}$ extent } \\
\hline & Mean & $\mathrm{SD}$ & Mean & $\mathrm{SD}$ \\
\hline Urban (\%) & 14.7 & 15.5 & 14.4 & 8.9 \\
\hline Irrigated (\%) & 20.4 & 27.7 & 32.8 & 22.8 \\
\hline Non-irrigated (\%) & 37.7 & 33.9 & 29.0 & 22.8 \\
\hline Grassland (\%) & 13.4 & 20.1 & 10.7 & 12.2 \\
\hline Scrubland (\%) & 12.8 & 15.5 & 11.6 & 8.2 \\
\hline Woodland (\%) & 0.8 & 2.2 & 1.1 & 1.2 \\
\hline Elevation $\min (\mathrm{m})$ & 133.1 & 65.4 & 122.7 & 56.1 \\
\hline Elevation max (m) & 138.7 & 69.4 & 152.2 & 81.2 \\
\hline Elevation mean (m) & 135.8 & 67.3 & 135.4 & 66.2 \\
\hline Elevation SD (m) & 2.4 & 2.4 & 6.9 & 7.8 \\
\hline Distance_colony (m) & $1,644.9$ & 990.6 & $1,644.9$ & 990.6 \\
\hline
\end{tabular}

Table 4 Loadings of the PCs, extracted from the PCA, and their percentage of variance, at the $100 \mathrm{~m}$ extent.

\begin{tabular}{|c|c|c|c|c|}
\hline $\begin{array}{l}\text { Predictor } \\
(\% \text { of variance) }\end{array}$ & $\begin{array}{l}\text { PC1a* } \\
(35.1)\end{array}$ & $\begin{array}{l}\text { PC2a } \\
(16.3)\end{array}$ & $\begin{array}{l}\text { PC3a } \\
(13.1) \\
\end{array}$ & $\begin{array}{l}\text { PC4a } \\
(10.9) \\
\end{array}$ \\
\hline Urban & & & + & 0.873 \\
\hline Grassland & & + & 0.585 & -0.555 \\
\hline Irrigated & - & & -0.671 & - \\
\hline Woodland & & + & -0.655 & \\
\hline Non-irrigated & + & -0.719 & & \\
\hline Scrubland & & 0.770 & & \\
\hline Distance_colony & & -0.587 & & \\
\hline Elevation min & 0.974 & & & \\
\hline Elevation max & 0.979 & & & \\
\hline Elevation mean & 0.977 & & & \\
\hline Elevation SD & 0.760 & & + & \\
\hline
\end{tabular}

${ }^{*}$ Only loadings larger than 0.5 are shown; for loadings with values between 0.2 and 0.5 only the sign is shown.

$\mathrm{PC} 1 \mathrm{a}$ is an elevation component, $\mathrm{PC} 2 \mathrm{a}$ a habitat component, $\mathrm{PC} 3 \mathrm{a}$ a habitat-distance component, $\mathrm{PC} 4 \mathrm{a}$ a habitat component.

Table 5 Loadings of the components extracted from the PCA, and its percentage of variance, at the $500 \mathrm{~m}$ extent.

\begin{tabular}{|c|c|c|c|c|}
\hline $\begin{array}{l}\text { Predictor } \\
\text { (\% of variance) }\end{array}$ & $\begin{array}{l}\mathrm{PC}{ }^{*}{ }^{*} \\
(40.0)\end{array}$ & $\begin{array}{l}\mathrm{PC} 2 \mathrm{~b}^{*} \\
(14.7)\end{array}$ & $\begin{array}{l}\mathrm{PC} 3 b^{*} \\
(13.4)\end{array}$ & $\begin{array}{l}\mathrm{PC} \mathrm{b}^{*} \\
(12.5)\end{array}$ \\
\hline Woodland & & 0.732 & & \\
\hline Urban & - & -0.702 & + & \\
\hline Irrigated & -0.621 & 0.570 & & - \\
\hline Non-irrigated & 0.640 & - & - & - \\
\hline Grassland & & & & 0.917 \\
\hline Elevation min & 0.957 & & & \\
\hline Elevation max & 0.976 & & & \\
\hline Elevation mean & 0.974 & & & \\
\hline Elevation SD & 0.837 & & & + \\
\hline Scrubland & & + & 0.669 & + \\
\hline Distance colony & & & -0.794 & \\
\hline
\end{tabular}

* Only loadings larger than 0.5 are shown; for loadings with values between 0.2 and 0.5 only the sign is shown.

$\mathrm{PC} 1 \mathrm{~b}$ is a habitat-elevation component, $\mathrm{PC} 2 \mathrm{~b}$ a habitat component, $\mathrm{PC} 3 \mathrm{~b}$ a habitat-distance component, $\mathrm{PC} 4 \mathrm{~b}$ a habitat component. 
Table 6 Model coefficients and their significance for QPM1 at $100 \mathrm{~m}$ extent analysis.

\begin{tabular}{lllll}
\hline Predictor & Coefficient & Standard error & $t$ value & $\operatorname{Pr}(>|t|)$ \\
\hline Intercept & 1.404 & 0.129 & 10.885 & $0.000^{* * *}$ \\
Dummy_fmargins & 0.013 & 0.292 & 0.047 & 0.962 \\
Dummy_elecwires & -0.307 & 0.148 & -2.061 & $0.040^{*}$ \\
PC1a & 0.120 & 0.064 & 1.865 & 0.064. \\
PC2a & -0.145 & 0.061 & -2.365 & $0.019^{*}$ \\
PC3a & 0.222 & 0.061 & 3.614 & $0.000^{* * *}$ \\
PC4a & -0.001 & 0.060 & -0.018 & 0.985 \\
\hline
\end{tabular}

Significance level: $0{ }^{\text {,*** }} 0.001^{\text {,**1 }} 0.01^{\text {, }^{*}} 0.05$ '.' 0.1 ' ' 1 .

Table 7 Model coefficients and their significance for QPM2 at $500 \mathrm{~m}$ extent analysis.

\begin{tabular}{lllll}
\hline Predictor & Coefficient & Standard error & $t$ value & $\operatorname{Pr}(>|t|)$ \\
\hline Intercept & 1.452 & 0.132 & 11.001 & $0.000^{* * *}$ \\
Dummy_fmargins & -0.051 & 0.300 & -0.173 & 0.863 \\
Dummy_elecwires & -0.366 & 0.152 & -2.410 & $0.017^{*}$ \\
PC1b & 0.122 & 0.066 & 1.835 & 0.068. \\
PC2b & -0.116 & 0.063 & -1.841 & 0.067. \\
PC3b & -0.102 & 0.062 & -1.633 & 0.104 \\
PC4b & 0.093 & 0.062 & 1.501 & 0.135 \\
\hline
\end{tabular}

Significance level: $0{ }^{\text {,***}} 0.001^{\text {,**1 }} 0.01^{\text {, }^{*}} 0.05$ '.' $0.1^{\prime \prime}$ ' 1 .

agricultural and natural habitat components; $\mathrm{PC} 1 \mathrm{~b}$

was positively and $\mathrm{PC} 2 \mathrm{~b}$ was negatively associated with lesser kestrel abundance, respectively (Table 7).

Presence of electricity facilities was a significant explanatory variable for foraging lesser kestrel abundance at both extents, while presence of field margins was not a significant predictor in any of the models (Table 7).

\subsection{Nesting and Foraging Lesser Kestrels in the SPAs}

Based on the GIS-based analysis of the SPAs under their current extent, the $25 \%$ of the colonies and approximately $40 \%$ of foraging points are outside the SPAs (Fig. 1). The SPA GR1420011 covers very small areas around bird colonies in eastern and western sites. Colonies situated at the western boundaries of the study area are not included in the SPAs at all (Fig. 1). When the boundaries of the SPAs are extended, based on the $3 \mathrm{~km}$ radius buffer zone around each breeding site, they include (except for all colonies) $86 \%$ of the foraging observation points (Fig. 1). Concerning habitat type coverage, the current
SPAs include $14 \%$ of irrigated land, $27 \%$ of non-irrigated land and $11 \%$ of grasslands and fallow land. When the SPAs boundaries are extended by the $3 \mathrm{~km}$ buffer zone around colonies, they include 35\% of irrigated, $26 \%$ of non-irrigated land and $11 \%$ of grasslands and fallow land.

\section{Discussion}

\subsection{Foraging Habitat Selection of Lesser Kestrels}

The foraging habitat analysis demonstrated that abundance of foraging lesser kestrel was positively associated with non-irrigated agricultural land (mostly cereals) and natural habitats (grasslands) in the study area. Based on outcomes of foraging observation points, cereal fields support more birds than any other habitat type. Similar studies in the Western Mediterranean found that cereals are a highly preferred foraging habitat by lesser kestrels $[12-14,16$, $18,19,21,38,55]$. Grasslands (including pastures and fallow land) are also considered as an optimal foraging habitat for breeding lesser kestrels in the Iberian Peninsula $[12,14,19,56]$. This is because 
they are rich in prey availability, mainly insects, including Orthoptera, Coleoptera, etc. [12, 57]. In diet analyses studies, Orthoptera were identified as lesser kestrel's most favourable prey items [16, 17].

Foraging lesser kestrel abundance was negatively associated with irrigated land (mainly cotton), a habitat type that covers large areas in the study area [34]. Other studies highlight that birds do not forage on irrigated crops $[18,58]$, while Tella et al. [13] remarked that birds had very large home ranges in areas with irrigated fields compared to those smaller ones, in cereal cultivations. Cotton fields are poor habitats in prey because of the high agro-chemical inputs that make them toxic to invertebrate fauna [59]. Ursua et al. [60] found that field margins are important feeding habitats for breeding lesser kestrels in areas surrounded by irrigated farmland. However, selection of field margins as preferred foraging habitats for lesser kestrels was not documented in this study, probably due to the time of the year field work was conducted (see below). Yet, field margins are widely recognised as a significant foraging habitat for the species, supporting their preferred prey $[12,13,19$, 57, 60].

Foraging lesser kestrel abundance was negatively associated with scrubland and woodland. Researcher argue that in habitats with dense vegetation cover (i.e., scrubland, woodland, tree plantations and olive orchards), prey is likely to be less accessible or scarce [12] and birds avoid them [13, 14, 17, 20, 56, 60]. Besides, foraging range has been found to be larger in areas with inappropriate habitats, such as irrigated fields, forest and scrubland, compared to areas with non-intensive cultivations and birds make longer foraging trips to search for food $[13,18,21]$. On the contrary, birds are known to forage close to colonies (2-3 km) in areas with good quality habitats and during the chick rearing period [13, 14, 21]. The mean distance of foraging observation points to the colonies in the study area was relatively small $(1,645 \mathrm{~m})$, indicating good foraging habitats.
This study was conducted during chick rearing period, which could explain why cereals were used for foraging. It has been found that in summer, during chick rearing period, cereal stubble are rich in Orthoptera and are highly preferred by birds [13, 38, 55]. When cereals are harvested, birds follow the harvest machines and capture insects that can be easily seen and accessed [14, 34]. Thus, selection of certain habitats for feeding by the lesser kestrel in cultivated areas can be determined by the time the study is conducted, depending on vegetation structure that affects accessibility and abundance of their prey [12, 17, 38]. For example, in spring, cereal fields are dense, plants are tall and hunting of insects is difficult and this habitat is avoided by lesser kestrels and birds may use field margins to feed $[56,60]$. Further investigation would be needed for identifying the importance of field margins in the study area at different periods during the breeding season.

Abundance of forging lesser kestrels was also associated with the presence of electricity facilities. During field surveys at foraging observation points, electricity facilities were reported to be present at the approximately $75 \%$ of the feeding areas in the study area [34]. In areas lacking wires, birds were recorded to stand on bales of hay, the only prominent locations that could be used to search for prey. Presence of electricity wires and trees near colonies seems favourable for birds, particularly in the post-fledging and pre-migratory periods for roosting and resting [19, 61]. Zank and Kemp [62] found that perch-hunting in lesser kestrels was more successful than hover-hunting at non-breeding grounds, in South Africa, possibly because birds could make more accurate strikes and spend more time on assessing prey.

4.2 Designation of SPAs and Foraging Lesser Kestrel Habitats

The designated SPAs in the agro-ecosystems of the study area include the bulk of breeding lesser kestrel 
population in Greece, covering colonies surrounded partially by non-irrigated farmland (mainly cereals), the extent of which has dramatically shrunk in Central Greece over the last decades [34]. This study indicated that this land cover type remained of a preferred foraging habitat for the species. The significance of non-intensive cultivations also referred as high nature value (HNV) farmland (i.e., agro-ecosystems rich in biodiversity such as cereal cropping and semi-natural grasslands that sustain species of European and/or national conservation concern $[63,64]$ ) is illustrated in the European Action Plan of the lesser kestrel [4]. Schemes for maintaining and enhancing HNV farmland, both within and outside the network of protected areas would be needed for the preservation not only of priority species occurring in these habitats but for the overall farmland biodiversity, contributing to the target 2 (maintain and restore ecosystems) and the target 3 (achieving more sustainable agriculture and forestry) of the EU Biodiversity Strategy to 2020 [65].

The current SPAs do not cover all nesting sites and cannot be considered coherent enough to safeguard preferred foraging habitats for lesser kestrels, in order to improve their favourable conservation status as required by the European Species Action Plan [4]. First, the SPAs have small extent around lesser kestrel colonies in the eastern range of the species population, while all colonies in the western range of the population are left without protection. Moreover, the SPAs do not include good quality feeding sites, as they are comprised by the one third of lesser kestrel preferred feeding areas. As the colonies, mostly in recent years, are surrounded by inappropriate foraging habitats, such as intensively irrigated cultivations [34], a potential expansion of the current SPAs would cover all colonies but, in terms of foraging habitats, it would only increase the percentage of cotton within them. Coverage of preferred feeding habitats would not increase and other conservation actions would therefore be needed, such as the establishment of that hold elements, such as field margins, hedges and trees, fallow land and buffer strips under the EU CAP greening policy [43]. Rodriguez and Wiengand [66] recommend that restoration of field margins and sowing in-field strips can enhance biodiversity and improve the quality of foraging habitats in arable land.

Studies in the Iberian Peninsula also highlight inconsistency of the Natura 2000 network related to agro-ecosystems, showing that lesser kestrels are not well protected in farmlands that are under-represented in the network of protected areas in Spain [27]. While Traba et al. [25] showed that the SPAs network, in Spain, does not adequately cover the most important areas for steppe species (including lesser kestrels). Moreover, Santana et al. [28], who studied the effectiveness of conservation funding in Natura 2000 sites in Portugal for steppe birds (including lesser kestrels), found that only the specialised species were favoured, while the wider biodiversity remained under-protected. Guixé and Arroyo [22] who studied Montagu's harriers Circus pygargus, a species that also uses agricultural land to forage, suggest that conservation management should include larger radius around colonies to protect not only breeding but also feeding sites, as SPAs might include more inappropriate than appropriate foraging habitats. Underestimation of SPAs in agro-ecosystems is, thus, a more broad issue and should be addressed in a wider framework of protection for breeding lesser kestrels and other farmland birds in these ecosystems.

\section{Conclusions}

This study showed that cereals, a non-intensive cultivation and grasslands were highly preferred foraging habitats by lesser kestrels in the SPAs in agro-ecosystems of Central Greece. However, the current extent of the SPAs covers a small percentage of the species' foraging sites and cannot be considered coherent enough to support and protect the foraging habitats of lesser kestrels and other priority species in the study area. Proposals for efficient lesser kestrel 
and other priority species conservation in the agro-ecosystems of Greece should include actions, such as: (1) reconsideration of existing SPAs extent and better designation of new ones to encompass good quality foraging habitat and incorporate small or isolated populations in marginal areas of the species breeding ranges and (2) preservation of low-input farming systems and HNV farmland areas. Local stakeholders could benefit through the establishment of specific agri-environmental measures and effective EFA in arable land within the framework of the Greek Rural Development Programme under the CAP that would provide farmers with extra income when involved in the preservation of biodiversity in Natura 2000 sites or with compensations for potential losses due to the enforcement of protection measures in agro-ecosystems.

\section{Acknowledgments}

The present study was fully-funded by the Greek State Scholarships Foundation (I.K.Y). The authors would like to thank Dr. Alan Fielding, for his supervision and guidance throughout the course of the study. Special thanks are due to Dr. Javier Bustamante for his comments on the original thesis text, Dr. Aldina Franco, as well as an anonymous referee for comments on the original manuscript.

\section{References}

[1] European Commission. 2017. "Natura 2000 Sites: Birds Directives.” European Commission. Accessed April 5, 2015. http://ec.europa.eu/environment/nature/natura2000 /sites_birds/index_en.htm.

[2] Donald, P. F., Sanderson, F. J., Burfield, I. J., Bierman, S. M., Gregory, R. D., and Waliczky, Z. 2007. "International Conservation Policy Delivers Benefits for Birds in Europe." Science 317 (5839): 810-3.

[3] Tucker, G. M. 1997. "Priorities for Bird Conservation in Europe: The Importance of the Farmed Landscape.” In Farming and Birds in Europe: The Common Agricultural Policy and Its Implications for Bird Conservation, edited by Pain, D. J., and Pienkowski, M. W. London, UK: Academic Press, 79-116.

[4] Iňigo, A., and Barov, B. 2010. Species Action Plan for the Lesser Kestrel Falco naumanni in the European
Union. SEO/BirdLife and BirdLife International for the European Commission.

[5] Deinet, S., Ieronymidoy, C., McRae, L., Burfield, I. J., Foppen, R. P., Collen, B., and Bohm, M. 2013. Wildlife Comeback in Europe: The Recovery of Selected Mammal and Bird Species. London: Zoological Society of London.

[6] Gallo-Orsi, U. 2001. Saving Europe's Most Threatened Birds: Progress in Implementing European Species Action Plans. Wageningen: BirdLife International.

[7] Tucker, G. M., and Evans, M. I. 1997. Habitats for Birds in Europe: A Conservation Strategy for the Wider Environment. Cambridge, UK: BirdLife International.

[8] Burfield, I. J. 2009. "The Conservation Status and Trends of Raptors and Owls in Europe." Ambio. 37 (6): 401-7.

[9] Tucker, G. M., and Dixon, J. 1997. "Agricultural and Grassland Habitats." In Habitats for Birds in Europe: A Conservation Strategy for the Wider Environment, edited by Tucker, G. M. and Evans, M. I. Cambridge: BirdLife International, 267-325.

[10] Legakis, A., and Maragou, P. 2009. The Red Data Book of the Threatened Animals of Greece. Athens: Hellenic Zoological Society, Ministry of Environment, Energy and Climate Change. (in Greek)

[11] BirdLife International. 2017. European Birds of Conservation Concern: Populations, Trends and National Responsibilities. Cambridge, UK: BirdLife International.

[12] Donázar, J. A., Negro, J. J., and Hiraldo, F. 1993. "Foraging Habitat Selection, Land-Use Changes and Population Decline in the Lesser Kestrel Falco naumanni." Journal of Applied Ecology 30 (3): 515-22.

[13] Tella, J. L., Forero, M. G., Hiraldo, F., and Donazar, J. A. 1998. "Conflicts between Lesser Kestrel Conservation and European Agricultural Policies as Identified by Habitat Use Analyses." Conservation Biology 12 (3): 593-604.

[14] Franco, A. M. A., Catry, I., Sutherland, W. J., and Palmeirim, J. 2004. "Do Different Habitat Preference Methods Produce the Same Conservation Recommendations for Lesser Kestrels?" Animal Conservation 7 (3): 291-300.

[15] Franco, A. M. A., and Sutherland, W. J. 2004. "Modelling the Foraging Habitat Selection of Lesser Kestrels: Conservation Implications of European Agricultural Policies." Biological Conservation 120 (1): 63-74.

[16] Rodriguez, C., Johst, K., and Bustamante, J. 2006. "How Do Crop Types Influence Breeding Success in Lesser Kestrels through Prey Quality and Availability? A Modelling Approach." Journal of Applied Ecology 43 (3): 587-97.

[17] Rodriguez, C., Tapia, L., Ribeiro, K., and Bustamante, J. 2014. “Crop Vegetation Structure Is More Important than 
Crop Type in Determining Where Lesser Kestrels Forage." Bird Conservation International 24 (4): 438-52.

[18] De Frutos, A., and Olea, P. P. 2008. "Importance of the Premigratory Areas for the Conservation of Lesser Kestrel: Space Use and Habitat Selection during the Post-fledging Period." Animal Conservation 11 (3): 224-33.

[19] De Frutos, A., Olea, P. P., Mateo-Tomas, P., and Purroy, F. J. 2010. "The Role of Fallow in Habitat Use by the Lesser Kestrel during the Post-fledging Period: Inferring Potential Conservation from the Abolition of Obligatory Set-Aside." European Journal of Wildlife Research 56 (4): 503-11.

[20] Catry, I., Amano, T., Franco, A. M. A., and Sutherland, W. J. 2012. "Influence of Spatial and Temporal Dynamics of Agricultural Practices on the Lesser Kestrel." Journal of Applied Ecology 49 (1): 99-108.

[21] Catry, I., Franco, A. M. A., Rocha, P., Alcazar, R., Reis, S., Cordeiro, A., Ventim, R., Teodosio, J., and Moreira, F. 2013. "Foraging Habitat Quality Constrains Effectiveness of Artificial Nest-Site Provisioning in Reversing Population Declines in a Colonial Cavity Nester." PLoS ONE 8 (3): e58320. doi: 10.1371/journal.pone.0058320.

[22] Guixé, D., and Arroyo, B. 2011. "Appropriateness of Special Protection Areas for Wide Ranging Species: The Importance of Scale and Protecting Foraging, Not Just Nesting Habitats." Animal Conservation 14 (4): 391-9.

[23] Lopez-Lopez, P., Garcia-Ripolles, C., Soutullo, A., Cadahia, L., and Urios, V. 2007. "Are Important Bird Areas and Special Protected Areas Enough for Conservation? The Case of Bonelli's Eagle in a Mediterranean Area." Biodiversity and Conservation 16 (13): 3755-80.

[24] Martinez, J. E., Pagan, I., Palazon, J. A., and Calvo, J. F. 2007. "Habitat Use of Booted Eagles (Hieraaetus pennatus) in a Special Protection Area: Implications for Conservation." Biodiversity and Conservation 16 (12): 3481-8.

[25] Traba, J., De la Morena, E. L. G., Morales, B. M., and Suarez, F. 2007. "Determining High Value Areas for Steppe Birds in Spain: Hot Spots, Complementarity and the Efficiency of Protected Areas." Biodiversity and Conservation 16 (12): 3255-75.

[26] Fernandez, J. M., and Gurrutxaga, M. 2010. "Habitat Suitability Models for Assessing Bird Conservation Goals in Special Protection Areas." Ardeola 57: 79-90.

[27] Abellán, M. A., Martinez, J. E., Palazon, J. A., Esteve, M. A., and Calvo, J. F. 2011. "Efficiency of a Protected-Area Network in a Mediterranean Region: A Multispecies Assessment with Raptors." Environmental Management 47 (5): 983-91.

[28] Santana, J., Reino, L., Stoate, C., Borrralho, R., Carvalho,
C. R., Schindler, S., Moreira, F., Bugalho, M. N., Ribeiro, P. F., Santos, S. L., Vaz, A., Morgado, R., Porto, M., and Beja, P. 2014. "Mixed Effects of Long-Term Conservation Investment in Natura 2000 Farmland." Conservation Letters 7 (5): 467-77.

[29] Kukkala, A. S., Santageli, A., Butchart, S. H. M., Maiorano, L., Ramirez, I., Burfield, I. J., and Moilanen, A. 2016. "Coverage of Vertebrate Species Distributions by Important Bird and Biodiversity Areas and Special Protection Areas in the European Union." Biological Conservation 202: 1-9.

[30] Ministry of Environment \& Energy of Greece (MEEG). 2010. "Common Ministerial Decree 37338/1807/E103 on the Conservation of Wild Birds and Their Habitats Following the Birds Directive 79/409/EEC as Coded by the Recent 2009/147/EC." Accessed March 22, 2012. http://www.ypeka.gr/LinkClick.aspx?fileticket=T3r5Htyj $\mathrm{m} \% 2 \mathrm{Fo} \% 3 \mathrm{D} \&$ tabid=508. (in Greek)

[31] Ministry of Environment \& Energy of Greece (MEEG). 2012. "Amendment and Completion of the Common Ministerial Decree 37338/1807/E103 on the Conservation of Wild Birds and Their Habitats Following the Birds Directive 79/409/EEC as Coded by the Recent 2009/147/EC." Accessed March 22, 2014. http://www. ypeka.gr/LinkClick.aspx?fileticket=1zUfPc63nnE\%3D\&t abid=236\&language $=$ el-GR. (in Greek)

[32] Liarikos, K., Maragou, P., and Papagiannis, T. 2012. Greece Then and Now: Longitudinal Mapping of Land Cover, 1987-2007. Athens, Greece: WWF-Hellas. (in Greek)

[33] Loukas, A., Vasiliades, L., and Tzabiras, J. 2008. "Climate Change Effects on Drought Severity." Advances in Geosciences 17: 23-9.

[34] Galanaki, A. 2011. "Modelling the Breeding Habitat of the Lesser Kestrel Falco naumanni in an Agricultural Landscape in Central Greece.” Ph.D. thesis, Manchester Metropolitan University, UK.

[35] Bibby, C. J., Burgess, N. D., Hill, D. A., and Mustoe, S. H. 2000. Bird Census Techniques, 2nd ed.. London: Academic Press.

[36] Hardey, J., Crick, H., Werhham, C., Riley, H., Etharighe, B., and Thompsom, D. 2006. Raptors: A Field Guide for Surveys and Monitoring. Edinburgh: The Stationery Office.

[37] Franco, A. M. A., Palmeirim, J. M., and Sutherland, W. J. 2007. "A Method for Comparing Effectiveness of Research Techniques in Conservation and Applied Ecology." Biological Conservation 134 (1): 96-105.

[38] Negro, J. J., Donázar, J. A., and Hiraldo, F. 1993. "Home Range of Lesser Kestrels (Falco naumanni) during the Breeding Season.” In Biology and Conservation of Small Falcons: Proceedings of the Hawk and Owl Trust 
Conference, edited by Nicholls, M. K., and Clarce, R. London: The Hawk and Owl Trust, 144-50.

[39] Tella, J. L., and Forreo, M. G. 2000. "Farmland Habitat Selection of Wintering Lesser Kestrels in a Spanish Pseudo-Steppe: Implications for Conservation Strategies." Biodiversity and Conservation 9 (3): 433-41.

[40] Legendre, P., and Legendre, L. 1998. Numerical Ecology: Developments in Environmental Modelling, 2nd ed.. Amsterdam: Elsevier.

[41] Wiens, J. A. 2002. "Predicting Species Occurrences: Progress, Problems and Prospects." In Predicting Species Occurrences: Issues of Accuracy and Scale, edited by Scott, J. M., Heglund, P. J., Morrison, M. L., Haufler, J. B., Raphael, M. G., Wall, W. B., and Samson, F. B. Covelo, CA: Island Press, 739-49.

[42] Batáry, P., Dicks, L. V., Kleijn, D., and Sutherland, W. J. 2015. "The Role of Agri-environment Schemes in Conservation and Environmental Management." Conservation Biology 29 (4): 1006-16.

[43] Underwood, E., and Tucker, G. 2016. Ecological Focus Area Choices and Their Potential Impacts on Biodiversity. Report for BirdLife Europe and the European Environmental Bureau Institute for European Environmental Policy, London.

[44] USGS. 2006. Landsat TM Scene, WRS-2, Path 184, Row33, Level 1G. Sioux Falls. South Dakota: USGS. Accessed October 15, 2005. https://landsat.usgs.gov/ landsat-science-data-products.

[45] European Environmental Agency (EEA). 2000. CORINE Land Cover Technical Guide-Addendum 2000. EEA Report No. 40/2000.

[46] USGS. 2004. "Shuttle Radar Topography Mission, 1 Arc Second Scene SRTM_u03_n008e004, Unfilled Unfinished 2.0." Global Land Cover Facility, University of Maryland, College Park, Maryland. Accessed November 7, 2005. http://glcf.umd.edu/data/srtm/.

[47] Environmental Systems Research Institute (ESRI). 2006. ArcGIS (v.9.2) ESRI Conservation Program Statement.

[48] Beyer, H. 2004. Hawth's Analysis Tools for ArcGIS (v. 3.26).

[49] Quinn, G. P., and Keough, M. J. 2002. Experimental Design and Data Analysis for Biologists, 2nd ed.. Cambridge, UK: Cambridge University Press.

[50] Field, A. 2000. Discovering Statistics Using SPSS for Windows. London: Sage Publications.

[51] McCullagh, P., and Nelder, J. A. 1989. Generalised Linear Models: Monographs on Statistics and Applied Probability, 2nd ed.. London: Chapman \& Hall.

[52] Cox, D. R. 1983. "Some Remarks on Overdispersion." Biometrika 70 (1): 269-74.

[53] Zuur, A. F., Ieno, E. N., and Smith, G. M. 2007. Analyzing Ecological Data (Statistics for Biology and
Health). New York: Springer.

[54] R Development Core Team. 2008. R: A Language and Environment for Statistical Commuting (v. 2.8.1). Vienna, Austria: R Foundation for Statistical Computing.

[55] Bonal, R., and Aparicio, J. M. 2008. "Evidence of Prey Depletion around Lesser Kestrel Falco naumanni Colonies and Its Short Term Negative Consequences." Journal of Avian Biology 39 (2): 189-97.

[56] Garcia, J. T., Morales, M. B., Martinez, J., Inglesias, L., De la Morena, E. G., Suarez, F., and Vinuella, J. 2006. "Foraging Activity and Use of Space by Lesser Kestrel Falco naumanni in Relation to Agrarian Management in Central Spain.” Bird Conservation International 16 (1): 83-95.

[57] Rodriguez, C., and Bustamante, J. 2008. "Patterns of Orthoptera Abundance and Lesser Kestrel Conservation in Arable Landscapes." Biodiversity and Conservation 17: 1753-64.

[58] De Frutos, A., Olea, P. P., and Mateo-Tomas, P. 2015. "Responses of Medium- and Large-Sized Bird Diversity to Irrigation in Dry Cereal Agro-ecosystems across Spatial Scales." Agriculture, Ecosystems and Environment 207: 141-52.

[59] EEC. 2007. "Cotton Impact Assessment." Commission Staff Working Paper, Accompanying Document to the Proposal for a Council Regulation: Amending Regulation (EC) No. 1782/2003 Establishing Common Rules for Direct Support Schemes under the Common Agricultural Policy and Establishing Certain Support Schemes for Farmers, as Regards the Support Scheme for Cotton. Accessed March 12, 2008. http://ec.europa.eu/agriculture /capreform/cotton/impact_en.pdf.

[60] Ursua, E., Serrano, D., and Tella, J. L. 2005. "Does Land Irrigation Actually Reduce Foraging Habitat for Breeding Lesser Kestrels? The Role of Crop Types.” Biological Conservation 122 (4): 643-8.

[61] Franco, A. M. A., Marques, J. T., and Sutherland, W. J. 2005. "Is Nest Site Availability Limiting Lesser Kestrel Populations? A Multiple Scale Approach.” Ibis 147 (4): 657-66.

[62] Zank, C. M., and Kemp, A. C. 1996. "A Comparison of Hunting Behaviour by Lesser Kestrels Falco naumanni and Eastern Red-Footed Falcons Falco amurensis in Their Non-breeding South African Range." Ostrich 67 (2): 63-6.

[63] Institute for European Environmental Policy (IEEP). 2007. Final Report for the Study on HNV Indicators for Evaluation. Institute for European Environmental Policy for DG Agriculture. Accessed March 19, 2009. https://ieep.eu/uploads/articles/attachments/62b84fd4-14c 9-4561-998b-af6d98ea6810/hnv_indicator_report.pdf?v= 63664509711. 
[64] EEA. 2009. Distribution and Targeting of the CAP Budget from a Biodiversity Perspective. EEA Technical Report No 12/2009. European Environment Agency (EEA). Accessed May 20, 2010. http://www.eea. europa.eu/publications/distribution-and-targeting-of-the-c ap-budget-from-a-biodiversity-perspective.

[65] European Commission. 2016. "Biodiversity Strategy."
Accessed October 15, 2016. http://ec.europa.eu/ environment/nature/biodiversity/strategy/index_en.htm.

[66] Rodriguez, C., and Wiegand, K. 2009. "Evaluating the Trade-Off between Machinery Efficiency and Loss of Biodiversity-Friendly Habitats in Arable Landscapes: The Role of Field Size." Agriculture, Ecosystems and Environment 129 (4): 361-6. 